Tér és Társadalom 23. évf. 2009/4. 225-231. p.

Tér és Társadalom

XXIII. évf. 2009

4: $225-231$

\title{
VITA
}

\section{KRITIKA ÉS TÁRSADALOMELMÉLET - NÉHÁNY ÉRV A KRITIKAI FÖLDRAJZ „VÉDELMÉBEN”}

\section{TIMÁR JUDIT}

Nos, akkor „csapjunk bele a lecsóba”! Idézőjel ide vagy oda, abban a müfajban, amiben Beluszky Pál (2009) TÉT-ben közzétett vitaindítójára válaszolok, talán nem szükséges a szerzỏ oldalszámmal ellátott precíz hivatkozása. A kritikai földrajz kritikáját felvázoló esszéjének e szellemes megjegyzését nem azért választottam kiindulópontnak, mert ,tenyeremet dörzsölve" ízes szópárbajra készülök vele. Ismerve íráskészségét és humorát, ebben amúgy is alulmaradnék. Meg aztán, az ember nem éppen a példaképeivel szokott effélékre vállalkozni -, ha személyes megszólításommal nem ébreszti fel bennem a felelósségtudatot korábbi írásaim (Timár 2003a; 2003b) elöre nem látott, rajtam messze túlmutató következményeivel kapcsolatban, talán még az alábbi érvek felsorakoztatását is megfontoltam volna. Azért kapaszkodtam ebbe a mondatába, mert roppant szemléletesen tükrözi, hol érti félre, vagy legalábbis használja egyoldalúan Beluszky Pál a kritikai földrajzban a „kritikait”, és siklik ezért ítéletalkotása - szerintem - rossz vágányra. Vagy ha már a vágánynál tartunk: lehet, hogy épp most derül ki, mennyire eltérő pályán haladunk, s e párbeszéd segít végre tisztázni a gondolatrendszerekhez, irányzatokhoz kapcsolódó, a földrajzi tudás létrehozásáról, illetve újratermeléséről alkotott nézetek különbségeit? Esetleg pont ennek köszönhető, hogy oly hosszú várakozás után társadalomelméleti vitát is folytathatunk a kortárs földrajzról ${ }^{1}$ ? Így legalább magyarázkodnom sem kell, hogy nem a „megtérítés” szándékával ragadtam tollat (bár megvallom, nem csekély örömmel töltene el, ha Beluszky Pált „köztünk” tudhatnám), sokkal inkább azért, hogy a kritikai földrajzzal most ismerkedókben eloszlassak esetleg felmerülő kételyeket, további félreértéseket.

Elöljáróban néhány megjegyzés ahhoz a gondolati tengelyhez, amire Beluszky Pál felfüzi mondandóját: úgy tünik, nem lelkesedik az új irányzatokért, azokért, amelyeket felsorolt, biztosan nem. Megjelenésüket mintha alapvetően müvelöik egyfajta - a fósodorban haladókkal vívott - versenyeként értékelné: „surranópályáknak", melyek arra valók, hogy a magukat oda „manőverező"k” (esetleg „prófétának” kikiáltók) az „újdonság erejét felhasználva” „megelözhessék pályatársaikat”. Pedig kellene elemzése végére nyilván belátnunk - a segítségükkel szerezhetỏ siker múlandó, hisz elóbb-utóbb olyan sorsra jutnak, mint a hazai szociálgeográfia, amely mára - még ha tagadhatatlan érdemeket is szerzett - lassan „,ki is kopott a szóhasz- 
Tímár Judit : Kritika és társadalomelmélet - Néhány érv a kritikai földrajz „védelmében".

Vita -Tér és Társadalom 23. évf. 2009/4. 225-231. p.

nálatból”, hogy egy másik „trendinek" adjon helyet. A kritikai földrajznak viszont még ennyi esélyt sem ad - azt állítja, az valójában „nincs is”.

Ha e gondolatmenetből az új irányzatok múló divatként kezelésére fókuszálnék, nagyon „adná magát” a tudomány fejlödésének Kuhn-féle (1922), paradigmaváltásokkal értelmezett felfogását segítségül hívó ellenérv, e nézetet azonban többek között a zárt rendszerben való gondolkodás, a társadalmi hatások nem kelló figyelembe vétele miatt szokták bírálni. Márpedig e helyütt - az egyéni érdekek szerepével szemben - épp a társadalmi kontextus fontosságára szeretném felhívni a figyelmet. Maradjunk ezért inkább egy konkrét hazai példánál - a történeti földrajzban (is) maradandót alkotó vitapartnerem gondolatmenete egy történeti párhuzamot juttat eszembe. Pályánk kezdetén, a szocializmus évtizedei alatt a gazdaságföldrajz nemcsak, hogy fösodorban, de - mondhatni - egyeduralmi pozícióban volt. Ezért ma már alig hihetö, hogy Teleki Pál, a magyarországi gazdaságföldrajz megteremtöje, néhány évvel túl a Magyar Földrajzi Társaság Gazdaságföldrajzi Szakosztálya létrehozásán, 1917-ben így ír a ,gazdasági földrajz mozgalmáról" szóló könyvfejezetében:

„Ma minden ember gazdasági földrajzról beszél. A párizsi kereskedelmi földrajzi társaság alapítása óta (1878) társulatok alakultak, folyóiratok indultak meg, de különösen a legutolsó 10-20 esztendő irodalma - a földrajzon kívül és belül -, tele van e szóval: gazdasági földrajz. De ha egyszer az ember utánanéz, hogy mi is az a gazdasági földrajz, csodálkozva látja, hogy azt még senki sem tudja." (Teleki 1996, 126-127)

Teleki - a kortárs külföldi gazdaságföldrajzi iskolák szemléletét elvetve s a francia emberföldrajzi irányzatból építkezve - saját definíciót alkot. Mégis, mint Györi Róbert (2001) rámutat, sem az ö gondolatai, sem Havass Rezső Gazdaságföldrajzi Szakosztály számára összeállított kutatási koncepciója nem termékenyítették meg az 1910-es években folyó munkát. A gazdaságföldrajz hazai felértékelödéséhez a világháború, illetve a békekötés idószakának kellett elérkeznie ${ }^{2}$. Hiába volt tehát már „,prófétája” az új irányzatnak - s jelentek meg mások is a „surranópályán" -, a megfelelö társadalmi igény s a diszciplína szélesebb értelemben vett intézményrendszeri feltételeinek kialakulásáig nem teremthetett iskolát (ami természetesen fordítva is igaz).

Nem véletlen, hogy én a kritikai geográfia, helyesebben annak elődje, a radikális földrajz szocializmusbeli hiányáért is elsösorban a társadalmi rendszert tettem felelőssé (Timár 2003b). A társadalom-, jobban mondva gazdaságföldrajz pozíciója, uralkodó térszemlélete, a társadalomelméletektöl való távolmaradása (illetve nem tudatosított tudományfelfogása) részben ennek következménye, részben maga is gátló tényezö volt. Nem egyének attitüdjéröl, kritikához való bátorságáról vagy bátortalanságáról szólt ezért a szociológusok munkáival való néhány összevetésem sem. Többek között Szelényi Iván súlyos társadalmi egyenlötlenségeket feltárt, s azokat a szocializmus redisztribúciójával magyarázó empirikus kutatásainak példájával, valamint késỏbbi önértékelésének tanulságaival arra (is) igyekeztem rámutatni, hogy értékválasztásokat kizáró pozitivizmusa miatt jó ideig még ezek az eredményei sem tủntek az uralkodó hatalom számára igazán veszélyesnek (politikailag 
Tímár Judit : Kritika és társadalomelmélet - Néhány érv a kritikai földrajz „védelmében". Vita -Tér és Társadalom 23. évf. 2009/4. 225-231. p.

fajsúlyosnak). E témánk szempontjából oly fontos gondolatsor megvilágítására hadd használjam ismét Szelényi $(1990,435)$ szavait:

„Ök az ideológiai tisztítótüzet a 'revizionisták' ellen készítették elö; természetes ellenségeik a Lukács-iskola revizionista, kritikai marxistái voltak, akik egy nemes marxi szocializmusképet kértek számon a 'létező szocializmusok' nem különösebben nemes vagy vonzó valóságától. Az akkori kultúrpolitika igazi ellenfélként a kommunista-szocialista hagyományból építkezỏ ideológiai kritikusokat tekintette: Heller Ágnest, Fehér Ferencet, Vajda Mihályt, Márkus Györgyöt, Kis Jánost, Bence Györgyöt vagy Haraszti Miklóst. Nekem ugyan Heller Ágnes, Márkus György személyes jó barátaim voltak, eszmeileg azonban sok szempontból a 'barikád' másik oldalán álltam. Én nemesak, hogy marxista nem voltam, hanem világnézetileg is elköteleztem magam a polgári, értékmentes, empirikus társadalomtudomány mellett. ... A polgári pozitivizmus elfogadhatóbbnak tetszett a hatalom akkori birtokosainak szemében, mint a lukácsi ihletésü kritikai marxizmus."

Ez az a polgári, értékmentes, empirikus társadalomtudomány, amelynek a földrajzban betöltött uralkodó pozíciója miatt én másként látom a korszakot. Készséggel elfogadom Beluszky Páltól, hogy az 1970-es években indított, hátrányos helyzetü területeket vizsgáló munkáik fontos szakpolitikai kritikákat fogalmaztak meg - ezek pozitívumait magam is kiemeltem (Timár 2003b) ${ }^{3}$. Talán abban is igaza van, hogy a településpolitikai viták az általános rendszerkritika előfutárainak bizonyultak (azt ő sem állítja, hogy eleve rendszerkritikák lettek volna ${ }^{4}$ ). Bár elsỏ látásra meglepőnek tủnhet, de azzal a végkövetkeztetéssel is egyetértek, hogy a napjainkban bírálatokat megfogalmazó (például a városi rangú és városi funkciójú települések közötti meg nem felelést „dokumentáló”), „masszív szakmai hátteret” felvonultató mindazon munkák, amelyek szerinte a kritikai földrajzos indíttatású vizsgálatoknál azért bírnak nagyobb meggyőző eróvel, mert értékmentesek, valóban nem tekinthetők kritikai geográfiainak. Amiben viszont egyáltalán nem osztom a véleményét, az a kritikai földrajz létezésének - részben ennek az érvelésnek a logikájából levezetett - tagadása.

No és ezen a ponton értuink el ahhoz a bizonyos „,rossz vágányhoz”, a köztünk lévő vita lényegi eleméhez. Beluszky Pál $(2009,205)$ szerint azért nincs, nem is lehet kritikai földrajz, mert, ,a 'valóság' geográfia által vizsgált szegmense alapos, okadatolt állapotának, folyamatainak feltárása” során felismert ,,meg nem felelés” tanulmányozása, közzététele, azaz - mint állítja - a kritika, „minden korrekt (társadalom)földrajzi kutatás ... szerves, magától értetódő része”. Bár a „meg nem felelés” tartalmának további közös boncolgatása még kínál némi esélyt a köztünk lévö konszenzus megteremtésére, a későbbiek (így a várossá nyilvánítással kapcsolatban föntebb már érintőlegesen idézett példa, hogy a „lecsóba csapás” mint a kritikai geográfusok egyetlen célja vádjáról már ne is beszéljek) arról gyỏznek meg, hogy ebből, a „kritikait” a hibakeresésre, szakértői kritizálásra szúkító értelmezésből adódik a félreértés. Pedig Don Mitchell (2003) a Tér és Társadalom már idézett tematikus számában szemléletesen kifejti, hogy magának a névadó angol „critical” szónak legalább három jelentése van, amiból csak az egyik a Beluszky Pál által is használt. A Nemzetközi Kritikai Geográfiai Csoport létrehozását motiváló szellemiségben azonban a másik két jelentés, így a „kritikus állapot, válság” - kapcsolódva 
Tímár Judit : Kritika és társadalomelmélet - Néhány érv a kritikai földrajz „védelmében".

Vita -Tér és Társadalom 23. évf. 2009/4. 225-231. p.

az átalakuláshoz -, valamint az ,alapvető fontosságú, élethez nélkülözhetetlen [dolog]" is szerepet játszott (Mitchell 2003). A csoport „Szándéknyilatkozatából” (Desbines-Smith 1999) s a kritikai geográfia számos későbbi jellemzéséből is kitủnik, hogy abban a „kritikai” a kritikai társadalomelméletek kifejlesztését és alkalmazását is jelenti, amivel pedig Beluszky Pál nem számol. Tény, hogy a kritikai földrajzra jellemző konceptuális pluralizmus miatt nem könnyü számba venni az ilyen elméleti megközelítéseket, de közéjük sorolható az anarchizmus, a környezeti elméletek (environmentalism), a feminizmus, a marxizmus, a posztmarxizmus, a posztkolonializmus, a posztstrukturalizmus, a pszichoanalízis s a szükebb értelemben vett (Frankfurti iskolai, habermasi) kritikai elmélet (Painter 2000). A szociologus Ben Agger $(2006,4)$ a többek között a geográfiában is alkalmazott kritikai társadalomelméleteknek hét tulajdonságát gyüjtötte csokorba. Itt most csak a két első, gondolatmenetünk szempontjából legfontosabbat kiemelve:

- A kritikai társadalomelmélet a pozitivizmussal több kérdésben is szembehelyezkedve azt állítja, hogy „a tudás nem egyszerúen reflexiója egy 'kinti' inaktív világnak, hanem természettudósok és teoretikusok aktív konstrukciója, olyanoké, akik szükségszerúen bizonyos (elö)feltevéseket tesznek az általuk tanulmányozott világokról, ezért nem szigorúan értékmentesek."

- Az ilyen elmélet hirdeti a (társadalmi) haladás lehetőségét. „Az a szerepe, hogy tudatosítsa a jelen társadalom elnyomó jellegét, s hogy demonstrálja egy ettöl minőségileg különböző jövő társadalom lehetőségét. Így a kritikai társadalomelmélet abban az értelemben politikai, hogy részt vesz a társadalmi változás létrehozásában."

Úgy vélem, ez a két - alább még tovább elemzett - jellemző magában hordozza a magyarázatot: amíg az elképzelhetö, hogy a Beluszky Pál értelmezésében vett „kritikára való elszánt törekvés” önmagában nem feltétlen teremt - mint írja - „más” földrajzot, a pozitivizmus ilyen elszánt, két- (sőt több-) oldalú tagadása annál inkább. Az 1960-as évek nyugati társadalmi mozgalmainak ösztönzó hatásán túl - a leíró regionális földrajzot felváltó - a geográfiát tértudományként értelmező paradigma pozitivizmusával, az értékmentességet hirdető, valójában azonban a tőkét kiszolgáló telephelyelméletekkel való határozott szembefordulás hívta életre a radikális földrajzot ${ }^{5}$, ami késóbb a társadalmi változásokhoz igazodva, azokra reagálva formálódott kritikai geográfiává (Peet 1998; Smith 2003; Johnston-Sidaway 2004; Hubbart et al. 2005). (Csak mellékesen jegyzem meg, hogy a radikális földrajz folyóiratának, az egy ideig szamizdatként müködő Antipode-nak az első 10 évfolyamában közzétett hallatlanul izgalmas vitáit olvasva sokkal inkább asszociálok egy csatamezöre, mint egy „surranópályájára”.)

Nos, ami az értékmentesség tagadását illeti, az világosan kiderül, hogy Beluszky Pál errỏl másként gondolkodik. Úgy véli, a kritikai geográfusok elkötelezettsége a társadalmi haladás mellett „csak ront a helyzeten” - miután produktumuk ,nem tuikrözi 'fénytörés nélkül' az 'állapotokat', folyamatokat ... kevesebbet használ, mint egy higgadt elemzés." Kérdezhetném itt azt is: pontosan kinek is használ kevesebbet? 
Tímár Judit : Kritika és társadalomelmélet - Néhány érv a kritikai földrajz „védelmében". Vita -Tér és Társadalom 23. évf. 2009/4. 225-231. p.

De maradjunk inkább a „fénytörés” problémájánál. Nem tudom persze, vajon pontosan ugyanazt értjük-e akár a „fénytörésen”, akár a másutt előkerủlő ,ízlésen”. Egy ebből kiinduló, az értékmentességról kibontakozó vita, s annak egy széles körü folytatása azonban - Beluszky Pál kezdeményezésének köszönhetỏen - végre felszínre hozhatná a nézetek sokszínúségét a hazai geográfiában is ${ }^{6}$. Így azt is, hogy itt nem az egyik vagy másik vélemény abszolút igazságáról, hanem két eltérô, de egymás mellett régóta megéló (sőt, valljuk be, esetleg saját egyéni kutatópályáinkon is könnyen keveredő, átalakuló) tudományfelfogásról van szó. A kettőnk közti rövid párbeszéd keretei között, s a kritikai földrajz „védelmében” talán elég azokra a más diszciplínákban vagy más országok társadalom-földrajzosai közt lefolytatott pozitivizmus-vitákban ${ }^{7}$ megfogalmazott érvekre hivatkoznom, melyekkel azonosulni tudok. Így David Harvey $(1974,23)$ gondolataira, aki azt írta le, hogy a kritikai társadalomtudományok szerint a tények és az értékek között mesterséges dualizmust alakítottak ki - „az az állítás, hogy a tudománynak ideológiamentesnek kell lennie maga is ideológiai állítás.” Bár a „másik oldalon” áll, jól rímel erre Szelényi Iván (1990) fentebb citált ỏnvallomása, miszerint ö világnézetileg is elkötelezte magát a polgári, értékmentes, empirikus társadalomtudomány mellett. $\mathrm{Az}$ értékvállalás fontos része, hogy tisztázzuk: kinek és milyen célból kutatunk. A nézőpontok eltéréseit szemléletesen érzékelteti a fogyatékosság földrajzát vizsgáló Rob Kitchin (1999,225), aki a kutatók morális felelősségét, társadalmi változások iránti igényét, politikához füződő viszonyát tanulmányozva öt lehetséges álláspontot különített el: Az első álláspontot képviselö kutatók ,úgy tekintenek saját szerepuikre, mint passzív szemlélóére, aki objektíven és semlegesen tanulmányozza a társadalmat." A második esetben a kutatók „elismerik saját szubjektivitásukat és a kutatott csoporthoz viszonyított sajátos társadalmi helyzetüket". Egyik esetben sem tartják azonban kutatói feladatnak, hogy társadalmi változások érdekében befolyásolják a politikai döntéshozást. A harmadik csoportba tartozók ,felismerik a változás szükségességét, de olyan eszközök segítségével keresnek alternatív jövőket, mint a növekvő tudatosság." Magát a diskurzust tekintik cselekvésnek, az írást és oktatást pedig a világlátás megváltoztatására alkalmas közvetítőknek. A negyedik álláspontot magukénak tudók ,felismerik kutatásukban a hatalmi egyenlőtlenségeket, és olyan kutatási stratégiákra törekszenek, amelyek képessé teszik kutatási alanyaikat arra, hogy akár maguk keressék az igazságot, vagy akár a kutatáson keresztuil tegyék azt”. Az ötödik csoportba azok tartoznak, akik „felismerik a változás szükségességét, és akik kifejezetten saját politikai és társadalmi akcióikon keresztül igyekeznek változtatni".

Ebben az értékelésben is egyértelmü, hogy e széles skálán az utóbbi álláspontokat képviseló kritikai geográfusok társadalmi változásokat igyekeznek elérni kutatásaikkal, emancipatív tudást kívánnak nyújtani. A Nemzetközi Kritikai Geográfiai Csoport „Szándéknyilatkozata” szerint olyan változások támogatásáról van szó, amelyek a kapitalista kizsákmányolást, a nemi, faji és szexuális orientáltság alapján történő elnyomást, az imperializmust, neoliberalizmust, nacionalista agressziót és környezetrombolást bontják le (Desbines-Smith 1999). Talán e skála túl szélesnek látszik, de Beluszky Pál okfejtésével szemben - abból, hogy nem jutnak (esetleg nem is szándé- 
Tímár Judit : Kritika és társadalomelmélet - Néhány érv a kritikai földrajz „védelmében".

Vita -Tér és Társadalom 23. évf. 2009/4. 225-231. p.

koznak) a kritikai földrajzosok konszenzusra az alkalmazott kritikai társadalomelméletek valamelyikének privilegizálásában, semmiképp sem következhet az „étlap” olyan bővítése, amibe például az ultrakonzervatív vagy a nacionalista nézetek is beleférnek (nem mondom, a „,vegetáriánus” egész jól illik a menübe). Szó sincs tehát arról, hogy az egyetlen célunk a „belecsapás” lenne, arról még kevésbé, hogy abban a lecsóban a paradicsom és paprika megfér a citrommal. De az valóban igaz: ha már belenyúlunk, nem csak a felszínt kavargatjuk.

Nem tudom persze, meddig marad meg a kritikai földrajz a jelenlegi formájában. Azért vette át a radikális földrajz helyét, mert a hatvanas évek forradalmi mozgalmai után az 1980-as évekre a világpolitika sokkal konzervatívabbá vált, $s$ jó néhány országban ,a tudományos élet radikalizmusának élét elvette az akadémiai fó áramlatba való betagozódás" (Smith 2003, 37). Mára nemhogy nem létezik a geográfiában a jobboldali eltolódással szemben a baloldali jelenlét megteremtésére szerződött kritikai geográfia, de sok helyütt elérte a mainstream pozíciót. A belső vitákban néhányan épp ettől, míg mások az egyértelmübb fókuszpont hiányától féltik az irányzat jövöjét (lásd például Mizuoka 2003; Smith 2003; Blomley 2009). A „kritikaiság" mibenlétéröl épp a 2002-es békéscsabai konferencián indított útjára éles nemzetközi vitát Ash Amin (2003) elöadásának Don Mitchell (2003) által megfogalmazott, a TÉT-ben is közölt bírálata. Jó lenne, ha mi is bekapcsolódnánk az ilyen diskurzusokba, s nemcsak helyet adnánk nekik. Magam az elméleti tudás gyarapításához rengeteget merítek ezekböl, mint ahogy Beluszky Pál vitaindítójából is. Csak remélni tudom, hogy mások is csatlakoznak hozzánk.

\section{Jegyzetek}

${ }^{1}$ Meg kell jegyezni, Beluszky Pál (1989) épp 20 éve már kezdeményezett egy vitát a geográfia lényegi kérdéseiröl. Hiába reagáltak azonban arra akkor is néhányan, s hiába lángolt fel mind a mai napig többször is vita a regionális tudományra is kiterjedve (részben épp a két diszciplína viszonyára koncentrálva), azoknak egyszer sem került a fókuszába társadalomelméleti megközelítések ütköztetése (amit nyilván többes szám elsỏ személyben is fogalmazhatnék).

${ }^{2}$ Györi Róbert (2001) összegzése mellett a gazdasági földrajz formálódásának történelmi meghatározottságáról lásd Hajdú Zoltán (2006) hasonló értékelését.

${ }^{3}$ Ettöl eltekintve komoly ösztönzést kaptam vitapartneremtől, hogy e korszak munkáit sokkal alaposabb vizsgálat alá vegyem.

${ }^{4}$ Egy korábbi írásában épp azt fogalmazza meg, hogy a településpolitikai viták kezdetekor a „földrajz buzgón bírálta az OTK gyakorlatát, ... ám alig-alig tett arra kísérletet, hogy megvizsgálja: a településhálózatban lezajló változások mely elemei táplálkoznak a gazdaság és társadalom átformálódásából, melyek szándékos beavatkozás eredményei, melyek a gazdasági szabályozás melléktermékei; melyek kívánatosak, melyek küszöbölhetök ki és így tovább. Pedig ez lett volna a kötelessége." (Beluszky 1989, 52)

${ }^{5}$ Meg kell jegyezni, hogy e szembefordulás egy másik irányzatot, a humanisztikus geográfiát is kitermelte. A humanisztikus geográfia radikális földrajztól való eltéréseinek bemutatása azonban már eltérítene e vita fö kérdéseitől.

${ }^{6}$ Ezt nem „önmagáért”, hanem azért tartom fontosnak, hogy a hazai geográfiát is felvértezzük társadalomelméletekkel, s például ne egyetlen ilyen témájú kortárs magyar nyelvü könyv (Mészáros 2000) állhasson könyvespolcainkon. 
Tímár Judit : Kritika és társadalomelmélet - Néhány érv a kritikai földrajz „védelmében". Vita -Tér és Társadalom 23. évf. 2009/4. 225-231. p.

TÉT XXIII. évf. 2009 - 4

Vita

231

${ }^{7}$ Nyilván ebből is látszik, hogy itt nem szủkítem le a „pozitivizmus-vitát” arra az 1960-as években az NSZK-ban lezajlott, ilyen néven elhíresült polémiára, ami alapvetỏen Jürgen Habermas és Karl Popper (továbbá Theodor Adorno és Hans Albert) között folyt (s részben épp ezért elnevezésében módszertanilag félrevezetö). Egyébként ennek álláspontjai közuil is segítségül hívhatnám Habermas gondolatait, hisz kifejti, hogy a szociológia nem lehet értékmentes: az empirikus szociológiában eleve kódolt értékek vannak jelen, s aki nem hajlandó ezek megvitatására, az a fennálló (rossz) rendet igenil, illetve járul hozzá az újratermeléséhez (lásd Kodaj 2007).

\section{Irodalom}

Agger, B. (2006) Critical Social Theories. An Introduction. Second Edition. Paradigm Publishers, Boulder-London.

Amin, A. (2003) Multietnicitás és az Európa-eszme. - Tér és Társadalom. 2. 13-35. o.

Beluszky P. (1989) Magánjelentés a (társadalom)földrajzról. - Tér és Társadalom. 1. 49-63. o.

Beluszky P. (2009) Maradékok boltja (Egy visszavonuló levelei). - Tér és Társadalom. 3. 205-209. o.

Blomley, N.K. (2009) Critical human geography. - Gregory, D.-Jonston, R.J.-Pratt, G.-Watts, M.Whatmore, S. (eds.) The Dictionary of Human Geography. $5^{\text {th }}$ Edition. Blackwel, Oxford. 123-124. o.

Desbines, C.-Smith, N. (1999) The International Critical Geography Group: Forbidden Optimism? Environment and Planning D: Society and Space. 18. 379-382. o.

Győri R. (2001) A magyar gazdaságföldrajz a két világháború között. - Nemes Nagy J. (szerk.) Geográfia az ezredfordulón. Regionális Tudományi Tanulmányok 6. Eötvös Loránd Tudományegyetem Regionális Földrajzi Tanszék, Budapest. 61-83. o.

Hajdú Z. (2006) Fodor Ferenc: a geográfus. - Fodor F. A magyar földrajztudomány története [1951](Az eredeti kézirat alapján sajtó alá rendezte Dövényi Z.) MTA Földrajztudományi Kutatóintézet, Budapest. XI-XIII. o.

Harvey, D. (1974) What kind of geography for what kind of public policy? - Transactions of the Institute of British Geographers. 63, 18-24. o.

Hubbardt, P.-Kitchin, R.-Bartley, B.-Fuller, D. (2005) Thinking Geographically. Continuum, London New York.

Johnston, R.J.-Sidaway, J.D. (2004) Geography \& Geographers. Sixth Edition. Arnold, London.

Kitchin, R. (1999) Morals and ethics in geographical studies of disability. - Proctor, J.D.-Smith, D.M. (eds.) Geography and Ethics. Routledge, London - New York. 223-236. o.

Kodaj D. (2007) A lényegen innen és túl. A pozitivizmus-vita dilemmái. - Replika. 60. December. 129-144. o.

Kuhn, T. (1922) A tudományos forradalmak szerkezete. Gondolat, Budapest.

Mészáros R. (2000) A társadalomföldrajz gondolatvilága. Szegedi Tudományegyetem Gazdaság- és Társadalomföldrajzi Tanszék, Szeged.

Mitchell, D. (2003) Kritikai geográfia: Kritikus bukás, kritikus siker. - Tér és Társadalom. 2. 83-86. o.

Mizuoka, F. (2003) Beszámoló a Nemzetközi Kritikai Földrajzi Csoport szándéknyilatkozatát megvitató mủhelybeszélgetésrỏl. - Tér és Társadalom. 2. 87-91. o.

Painter, J. (2000) Critical human geography. - Jonston, R.J.-Gregory, D.-Pratt, G.-Watts, M. (eds.) The Dictionary of Human Geography. $4^{\text {th }}$ Edition. Blackwel, Oxford. 126-128. o.

Peet, R. (1998) Modern Geographical Thought. Blackwell, Oxford.

Smith, N. (2003) Jelszavak és könyörtelen kritika: marxizmus és nemzetközi kritikai geográfia. - Tér és Társadalom. 2.37-51. o.

Szelényi I. (1990) Új osztály, állam, politika. Európa Könyvkiadó, Budapest.

Teleki P. (1996) A földrajzi gondolat története. Kossuth Könyvkiadó, Budapest. (Első kiadás: 1917)

Timár J. (2003a) Szerkesztői elöszó. - Tér és Társadalom. 2. 1-3. o.

Timár J. (2003b) Problémák és perspektívák: „Mi a teendő” a kialakulóban lévő kritikai geográfia számára Magyarországon? - Tér és Társadalom. 2. 53-65. o. 